\title{
KNOTTING OF AN EPIDURAL CATHETER: A CASE REPORT
}

\author{
R.A. Browne AND V.L. POliti
}

KNOT FORMATION in an epidural catheter is a very rare complication of the continuous epidural technique. We could find no description of it in the literature. This prompted us to report this case. Bonica, however, mentions it as one of the possible problems that may arise in using the continuous epidural technique.'

\section{Case Report}

A 22-year-old Gravida 2 was admitted to the maternity hospital in the first stage of labour. When cervical dilatation reached $6 \mathrm{~cm}$, a transparent Portex epidural catheter was easily inserted through a Tuohy needle at the L2-3 level, using the loss of resistance test with a syringe loaded with normal saline. At the time of insertion, it was considered that the catheter had been introduced further than desirable and, after removing the needle, it was withdrawn so that in the final position the $15 \mathrm{~cm}$ marking was at the skin. This left approximately $7 \mathrm{~cm}$ of catheter in the epidural space. The catheter was then taped in place and an initial injection of $5 \mathrm{ml}$ of lidocaine 1.5 per cent with adrenaline 1:200,000 was given.

After ninety minutes, a repeat dose of $5 \mathrm{ml}$ of the lidocaine solution with adrenaline was administered without any problem. Satisfactory analgesia was achieved. Sixty-nine minutes later, when the caput was on the perinium, $8 \mathrm{ml}$ of lidocaine solution 1.5 per cent was injected easily through the catheter. This provided excellent analgesia for the subsequent low forceps delivery, removal of the placenta, and suture of the episiotomy.

On attempted removal of the catheter only $5 \mathrm{~cm}$ of it could be withdrawn. It then appeared to stick. Further attempts at withdrawal merely caused stretching of the catheter. Comparison with a new catheter showed that approximately 2 $\mathrm{cm}$ were still in the epidural space.

At this stage a discussion was held between two anaesthetists who came to the conclusion that either a knot had been formed in the epidural

R.A. Browne, M.D., F.F.A.R.C.S. (Eng.); F.R.C.P.(C) and V.L. Politi, M.D., F.R.C.P.(C). McMaster University and Hamilton Civic Hospitals, Hamilton, Ontario.

Canad. Anaesth. Soc. J., vol. 26, no. 2, March 1979 space or the catheter had hooked around a nerve root.

An attempt to inject saline through the catheter showed its lumen to be completely obstructed. This tended to point to the possibility that the catheter had coiled on itself and a loose knot had formed on withdrawal to the $15 \mathrm{~cm}$ mark at the time of insertion which became tightly knotted on attempted withdrawal at the termination of the epidural technique.

$X$-rays of the spine (AP and lateral) were taken, but failed to show any catheter as it was not radio-opaque.

Experiments were then carried out with a new Portex catheter to discover how much tension the catheter could withstand before breaking. A knot was tied near the end of the catheter and it was held firmly under the thumbnail and subjected to slow tension and stretching. Three points were noted: (1) The catheter withstood considerable stretching with a reduction of external diameter before breaking (Figure 1b). (2) As the catheter stretched, the knot became tighter and smaller and approached the diameter of a normal catheter. (3) Eventually the catheter broke immediately proximal to the knot.

It was therefore concluded that a firm steady pull on the catheter in the patient would stretch the catheter, reducing the size of the knot so that it would probably pass through the ligamentum flavum, interspinous and supraspinous ligaments along the path previously formed by the Tuohy needle. These findings were discussed with an orthopedic surgeon who concurred with the plan of action.

The patient and her husband were informed of our opinion. They were told that there was a very good chance of removing the catheter in toto by a firm pull on it, but that if it did break there would be approximately 2 to $3 \mathrm{~cm}$ left behind in the epidural space; that if that occurred, the only way to remove it would be by an open operation which would involve a laminectomy type operation; that the catheter was made of an inert material and, if it did break, it probably would not cause any trouble if left alone.

After discussion, the patient and her husband decided that they wished us to attempt removal 


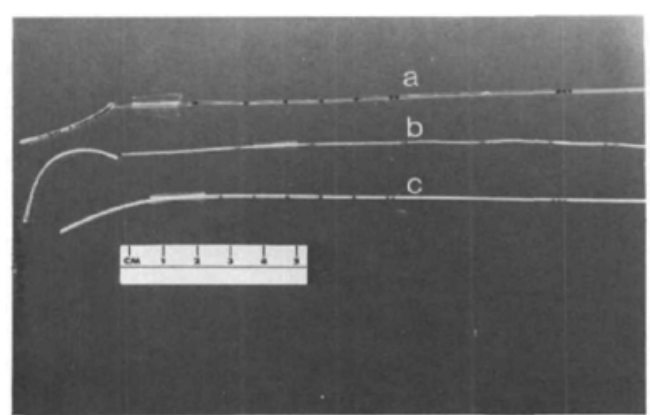

Figure I a. Catheter removed from the patient with knot. b. Catheter which was knotted and stretched until it broke. c. An unused new catheter.

by pulling on the catheter. It was decided to wait until the epidural block had worn off, in case the catheter was caught around a nerve root (an unlikely event). Pulling on it would then produce pain along the distribution of that nerve.

The catheter was then grasped gently with a pair of small artery forceps close to the skin and a firm steady pull was applied. A few seconds later, there was a sudden give and one centimetre of catheter was withdrawn. It stuck again momentarily, and then came out completely. The catheter with a tight knot $2.9 \mathrm{cms}$ from the tip is shown in Figure la, while Figure 1c shows a new catheter.

\section{Discussion}

Bromage reported that the catheter tends to be deflecled by blood vessels and nerve roots that lie in its path, curling up or doubling back after passing only a short distance in the direction in which it started. ${ }^{2}$

Moore states that if the catheter is inserted more than $5 \mathrm{~cm}$ beyond the level of the needle, it may curl back. It may then kink, turn $180^{\circ}$ and go in the direction opposite to that intended, pass out of an intervertebral foramen, wrap around a nerve, or a combination of the se. ${ }^{3}$

An excellent study was carried out by Muneyuki, Shirai and Inamoto ${ }^{4}$ who inserted polyethylene and polyvinyl catheters into the epidural space at both the lumbar and thoracic levels. They then took $X$-rays after injecting radio-opaque material. They showed that a catheter inserted more than $4.5 \mathrm{~cm}$ into the lumbar epidural space tended either to curl or to double back and that the catheter tip tended to be situated within three segments of the puncture site. For a thoracic puncture, however, the catheter could be consistently advanced for an average distance of $10 \mathrm{~cm}$ without curling. They attributed this fact to the oblique direction of the needle required in a thoracic epidural insertion. It therefore appears that inserting longer lengths of catheter is safer in the thoracic than in the lumbar area.

We learned from this experience that:

(1) As short a length of catheter as possible should be placed in the lumbar epidural space. The majority of modern catheters have markings on them. The one supplied by Portex has a single mark at $5 \mathrm{~cm}, 6 \mathrm{~cm}, 7 \mathrm{~cm}, 8 \mathrm{~cm}$, and $9 \mathrm{~cm}$; a double mark at $10 \mathrm{~cm}$, triple marker at $15 \mathrm{~cm}$, and four marks at $20 \mathrm{~cm}$. The hub of the needle approximates to the double mark at $10 \mathrm{~cm}$. If the catheter is inserted until the triple marker is at the hub of the needle, after the epidural space has been reached, then this will result in approximately 5 $\mathrm{cm}$ of catheter being left in the epidural space. The distance of the epidural space from the skin is then of no consequence. Curling with subsequent knotting would then be very unlikely. However, if the catheter is inserted beyond the triple mark at the hub, even though it may be pulled back later, the scene has been set for the possibility of curling and knot formation.

(2) The patient and spouse should be informed about what has happened and how it is proposed to try to remedy the situation. Let them take part in any decisions to be made. This is particularly important if later medico-legal considerations arise.

(3) If a knot forms near the end of the catheter, test a similar catheter to discover how much stretching-it can take before breaking.

(4) A gentle pull may tighten the knot and make it small enough to be pulled through before the breaking tension of the catheter is reached.

\section{SUMMARY}

Difficulty with removal of an epidural catheter is described due to formation of a knot near the end of the catheter.

It is stressed that in the lumbar area an epidural catheter should never be inserted more than $5 \mathrm{~cm}$ into the epidural space, as curling with knot formation may occur.

Removal may be attempted by pulling on the catheter if testing of a similar catheter indicates that it will withstand the tension.

The patient and the spouse should be kept informed and involved in the decision-making for medico-legal reasons. 


\section{RÉSUMÉ}

La formation d'un nceud sur un cathéter peut compliquer la technique d'anesthésie épidurale continue. Cette éventualité a déjà été soulevée par Bonica et les auteurs en rapportent un cas.

Il s'agil d'une secondipare de 22 ans chez qui un cathéter transparent de marque Portex a été introduit pendant le premier stage du travail jusqu'à ce que la ligne indiquant $15 \mathrm{~cm}$ soit à la peau, ce qui laissait $7 \mathrm{~cm}$ de cathéter à l'intérieur de l'espace épidural.

Une analgésie satisfaisante fut obtenue après trojs injections de lidocaine 1.5 pour cent avec adrénaline 1:200,000. Après l'accouchement, la tentative de retrait du cathéter s'avéra infructueuse et la traction exercée ne fit qu'étirer le cathéter. Après consultation avec un collègue anesthésiste et un chirurgien orthopédique, deux éventualités furent retenues: soit qu'un nœud s'était formé à l'extrémité du cathéter, soit que le cathéter s'était enroulé autour d'une racine nerveuse.

En experimentant avec un cathéter du même type, on réalisa qu'en étirant le cathéter le nœud s'amenuisait et qu'on pourrait probablement re- tirer le cathéter coincé en exerçant une traction ferme dans l'axe dans lequel il avait été introduit.

Ce qui fut fait dès que la patiente eut retrouvé toute sa sensibilité. La figure la montre le cathéter avec le nceud. La figure $1 b$ fait voir le cathéter noué après étirement jusqu à la brisure et la figure lc un cathéter intact.

A la région lombaire, les auteurs suggèrent d'insérer le cathéter jusqu'à ce que la troisième ligne apparaisse au pavillon de l'aiguille; ce qui laisse une longueur de 5 centimètres à l'intérieur de l'espace épidural. C'est en poussant plus profondément qu'on risque la formation d'un nceud.

\section{REFERENCES}

1. Bonica, J.J. Principles and practice of obstetric analgesia and anesthesia. 1st ed., Philadelphia: F.A. Davis Co. (1967).

2. Bromage, P.R. Spinal epidural analgesia. Ist ed. Edinburgh and London, E. \& S. Livingstone Ltd. (1954).

3. MOORE, D.C. Regional block. 4 th ed., Charles $C$. Thomas (1971).

4. Muneyuki, M., Shirai, K., \& Inamoto, a. Roentgenographic analysis of the positions of catheters in the epidural space. Anesthesiology 33 : 19 (1970).

\section{CORRECTION}

\section{ANAESTHETIC MANAGEMENT FOR CORONARY ARTERY BYPASS SURGERY}

EMERSon A. Moffitt

Canadian Anaesthetists' Society Journal 25: $462-467$ (November 1978)

In Table II, page 463 , the dose of pancuronium should be $0.08-0.1 \mathrm{mg} / \mathrm{kg}$. 